\title{
IS CADAVER STILL NEEDED IN MEDICAL EDUCATION?
}

Muhammad Mansyur Romi ${ }^{1 *}$, Nur Arfian ${ }^{1}$, Dwi Cahyani Ratna Sari ${ }^{1}$

${ }^{1}$ Department of Anatomy, Faculty of Medicine, Public Health and Nursing, Universitas Gadjah Mada, Yogyakarta - INDONESIA

\begin{abstract}
Background: Medical education has been developing very rapidly. Cadavers, which can serve as very important learning resources, need special concern for their availability and utility.

Methods: This narrative review is based on related articles freely downloaded which discuss the role and availability of cadavers worldwide. The recent Indonesian condition with Universitas Gadjah Mada as a case will be described.

Results: Cadavers play important roles in several aspects, from bioethics and behavioral development until clinical skills, in basic education and especially in postgraduate and advance clinical training. The availability of cadavers has declined significantly, and as a result, the impacts must be considered. Most cadavers are unidentified bodies, eventhough presently a body donation program is recommended as the alternative source.

Conclusion: Currently in Indonesia, timely participation is needed from various stakeholders to support effective and efficient cadaver availability and utility. Additional learning resources are needed to be developed in order to assure quality improvement of medical education.
\end{abstract}

Keywords: cadaver, medical education, bioethics, unidentified bodies, body donation.

\section{ABSTRAK}

Latar belakang: Pendidikan kedokteran mengalami perkembangan yang pesat. Cadaver sebagai sumber pembelajaran yang sangat bermakna bagi pendidikan kedokteran perlu perhatian dalam hal ketersediaan dan pemanfaatannya.

Metode: Tinjauan naratif ini membahas perkembangan peran cadaver dan ketersediaannya secara global, bersumber dari penelusuran naskah yang dapt diunduh secara bebas. Kondisi di Indonesia, khususnya di UGM ditampilkan sebagai gambaran.

Hasil: Cadaver dapat dimanfaatkan dalam berbagai aspek, mulai dari penegembangan bioetika dan perilaku hingga ketrampilan klinis, pada jenjang pendidikan dasar hingga keahlian klinis lanjut. Ketersediaan cadaver mengalami penurunan yang bermakna sehingga dampaknya perlu menjadi perhatian. Sumber cadaver hamper seluruhnya masih dari 'jasad tak dikenal' (unidentified bodies) meski telah disarankan untuk memasyarakatkan hibah jasad sebagai sumber pengganti.

Kesimpulan: Di Indonesia saat ini perlu ikhtiyar yang melibatkan berbagai pemangku kepentingan untuk mendukung ketersediaan dan pemanfaatan cadaver secara efektif dan efisien. Sumber pembelajaran pengganti sebagai tambahan perlu dikembangkan untuk menjamin peningkatan mutu pendidikan kedokteran.

Kata kunci: cadaver, pendidikan kedokteran, bioetika, jasad tak dikenal, hibah jasad.

*corresponding author, contact: romi.mm@ugm.ac.id 


\section{PENDAHULUAN}

Pendidikan kedokteran mengalami perkembangan pesat dalam berbagai aspeknya. Jumlah institusi pendidikan kedokteran tumbuh, demikian pula perkembangan kurikulum, termasuk metode dan sumber pembelajaran yang dilibatkan. Dalam pesatnya perkembangan pendidikan kedokteran tersebut terdapat suatu icon yang tetap aktual untuk dibahas, yaitu tentang diseksi (pembedahan) cadaver. ${ }^{1}$ Sebagai dasar utuk memahami struktur dan fungsi tubuh manusia, dapat dilacak bahwa diseksi cadaver telah berlangsung lebih dari dua millennia. ${ }^{2}$ Perjalanan panjang diseksi cadaver itu ternyata diwarnai sisi gelap dan masa pencerahan, yang juga berdampak terhadap pendidikan kedokteran. Beberapa kajian mengungkapkan bahwa pengajaran anatomi dan ilmu dasar lain mengalami pergeseran. Gambaran umum yang ditengarai adalah berkurangnya waktu dan fasilitas yang tersedia dalam bidang anatomi termasuk tenaga ahli yang menguasai anatomi, terutama anatomi klinis. ${ }^{3,4}$ Akibat lanjut yang mungkin terjadi telah dilontarkan oleh Ellis ${ }^{5}$ dan Older $^{6}$ bahwa ada risiko para klinisi, terutama yang menangani pembedahan, harus menjalankan tugas meskipun dengan pemahaman anatomi yang tidak sebaik generasi terdahulu. Menurunnya pengetahuan anatomi disebut sebagai salah satu penyebab meningkatnya 'salah bedah' (surgical errors) dan konsekuensi bertambahnya perkara mediko-legal.,6 Untuk mengatasi kecenderungan penurunan mutu tersebut perlu ikhtiyar yang melibatkan berbagai pemangku kepentingan dan pakar. Ada beberapa pokok permasalahan yang perlu dibahas yaitu ketersediaan cadaver, pemanfaatan diseksi cadaver dan penempatannya yang tepat dalam kurikulum pada berbagai jenjang pendidikan kedokteran yang terus berkembang.

\section{METODE}

Tulisan ini merupakan tinjauan naratif (narrative review) yang mencoba mengulas bagaimana peran dan posisi pembedahan cadaver dari masa ke masa, termasuk bagaimana ketersediaannya dalam beberapa dasawarsa terakhir. Bahan tinjauan bersumber terutama pada naskah yang dilacak lewat
PubMed dengan kata kunci diseksi cadaver (cadaver dissection) dan pengajaran anatomi (anatomy teaching) yang dapat diunduh dengan bebas. Dari naskah yang terkumpul dipilih yang relevan dengan permasalahan yang dibahas. Selanjutnya secara umum akan digambarkan kondisi di Indonesia dan khususnya perkembangan yang terjadi di Fakultas Kedokteran UGM.

\section{HASIL DAN PEMBAHASAN \\ Sejarah Diseksi Tubuh Manusia}

Pembedahan manusia secara sistematik (systematic human dissection) dapat ditelusur kejadiannya sejak abad ketiga SM oleh dua tokoh Yunani yaitu Herophilus dan Erasistratus di Alexandria. Keduanya kemudian dijuluki sebagai Bapak Anatomi. Pada abad sebelumnya Aristoteles telah mengawali dengan melakukan pembedahan terhadap hewan namun tidak pada manusia, dan merupakan tokoh yang pertama kali memperkenalkan istilah "anatomi". Terobosan yang dirintis oleh kedua orang Yunani tersebut meretas berbagai hambatan kultural dan kepercayaan saat itu sehingga dikenal sebagai "saat yang menakjubkan dalam sejarah sains" (stunning moment in the history of science). Kondisi yang memungkinkan kejadian luar biasa itu terjadi antara lain karena atmosfir ilmiah, berkumpulnya intelektual dari berbagai penjuru dan peran penguasa (royal intervention) di Alexandria yang progresif pada masanya. ${ }^{7-9}$ Sejarah mencatat bahwa diseksi manusia hanya berlangsung sebentar, kemudian tidak berlanjut dan menghilang sampai beberapa abad atau lebih dari 1500 tahun lamanya. Pada abad kedua Masehi hadir Claudius Galen (129-216M) yang mengajarkan kembali peran anatomi sebagai dasar kedokteran, meskipun hanya bersumber dari diseksi kera dan bukan manusia. Hasil karya mereka umumnya ditulis dalam bentuk narasi dan belum dilengkapi dengan gambar atau ilustrasi. Sangat disayangkan bahwa warisan naskah deskriptif yang berharga dari Herophilus dan Erasistratus sebagai hasil diseksi konon sepenuhnya punah dengan terbakarnya Alexandria pada 389 M. ${ }^{2}$

Selama abad pertengahan perkembangan pemikiran rasional, penelitian dan perkembangan ilmu di Eropa lumpuh dibawah tekanan otoritas gereja. Dunia 
kedokteran hanya mengandalkan ilmu-ilmu dasar yang diwariskan oleh Aristoteles dan Galen tanpa mempertanyakan kesahihannya. Diseksi manusia dianggap perbuatan menista tuhan maupun agama dan dilarang sepanjang lebih dari 15 abad. Pada saat Eropa dirundung abad kegelapan, ilmu kedokteran tumbuh subur di semenanjung Arabia, terutama di Baghdad yang dikembangkan para ilmuwan Muslim seperti Muhammad Al-Razi/Rhazes (865/862925/930), Ibn Al-Haytham (965-1040), Abu Ibnu Sina/Avicenna (980-1037), Ibn Al-Nafis (12101288), dan Mansur Ibn Ilyas (1380-1422). ${ }^{10,11}$

Sejak abad 12 gereja tidak lagi melarang diseksi manusia meski ada pembatasan. Pada th 1231 kaisar Romawi Frederck II (1194-1250) menerbitkan dekrit yang memberi mandat untuk diseksi tubuh manusia setidaknya sekali dalam lima tahun. Agenda ini ditujukan untuk kajian anatomi dan wajib dihadiri oleh setiap orang yang menjalani praktek medis atau pembedahan. Sekitar akhir abad 13 batasan terhadap diseksi dan autopsi dilonggarkan. Diseksi yang disaksikan khalayak mulai dikerjakan oleh Mondino de Liuzzi (1275-1326) pada th 1315 di Bologna. Jasad yang dibedah adalah para pelaku kriminal yang dieksekusi, dikerjakan di universitas untuk kajian anatomi yang terbatas selama empat hari karena saat itu belum dikenal teknik pengawetan cadaver. Diseksi umumnya berlangsung satu sampai dua kali setiap tahun dengan standar baku yang ketat. Setiap diseksi harus menghadirkan Lector yang menguasai anatomi merujuk pada naskah Anatomia Mondini karya de Liuzzi dengan membacakan dan menjelaskannya, seorang Ostensor yang memberi petunjuk bagian tubuh mana yang perlu dibedah, dan seorang Sector yang melakukan pembedahan. Namun selanjutnya dengan berbagai alasan dan kepentingan diluar kedokteran, termasuk seni rupa, diseksi makin merebak dan dilakukan secara tidak baku. Dampak tingginya keperluan terhadap cadaver mendorong terjadinya malpraktek masa itu, seperti perampasan mayat, pembongkaran dan pencurian mayat dari pekuburan, bahkan konon hingga dengan melakukan pembunuhan. ${ }^{2}$

Buku teks anatomi paling awal yang dilengkapi ilustrasi antara lain adalah karya Mansur Ibn Ilyas
(1380-1422) yang dikenal sebagai Tahsrihi-i-badani-insani-Mansuri atau Mansur's Anatomy. Dengan meningkatnya minat masyarakat terhadap diseksi manusia, termasuk para seniman lukis terbaik di era Renaissance, buku teks anatomi dengan ilustrasi yang sesuai aslinya (naturalis) makin berkembang. Kecenderungan itu terus tumbuh dan pada abad ke-15 hadir Andreas Vesalius (1514-1564) yang menghasilkan karya De Humani Corporis Fabrica dan kemudian digelari Bapak Anatomi Modern. Vesalius tercatat sebagai ilmuwan kedokteran yang menekankan bahwa untuk belajar anatomi seseorang harus mengerjakan diseksi mandiri. Selain itu Vesalius dikenal kritis terhadap pandangan Galen dalam berbagai karyanya, sebagaimana juga telah dilakukan oleh Muhammad Al-Razi (865/862-925/930) yang menulis Al-Shukuk 'ala Jalinus atau Doubts on Galen. ${ }^{10,12}$

Dengan makin berkembangnya teknologi untuk ilustrasi dan visualisasi, maka buku teks dan Atlas Anatomi menjadi makin beragam, ada yang bersumber dari jasad nyata yang asli hingga hasil daya cipta maya. Selain itu dengan teknik pengawetan yang terus berkembang, kini proses plastinasi dapat mengubah jaringan cadaver bertahan utuh seterusnya tanpa pembusukan. Sumber pembalajaran anatomi saat ini sangat kaya dan inovatif hingga dilengkapi dengan simulasi dan tampilan tiga dimensi (3D).

\section{Pemanfaatan Cadaver}

Diskusi tentang pemanfaatan cadaver masih terus berlanjut. Pada umumnya institusi pendidikan kedokteran tetap memanfaatkan cadaver meski dengan intensitas yang beragam, diseksi langsung, proseksi oleh ahli anatomi, atau menggunakan hasil plastinasi. Pemanfaatan cadaver memang membawa konsekwensi yang harus ditanggung, antara lain biaya sarana prasana yang tinggi dan waktu pelaksanaan yang panjang. Masalah lain yaitu ketersediaan cadaver serta tenaga ahli anatomi yang menguasai teknik diseksi juga makin berkurang. ${ }^{13,14}$ Karena itu beberapa institusi telah sepenuhnya meninggalkan pemanfaatan cadaver dan mengganti dengan sumber belajar anatomi lainnya. ${ }^{15}$ Namun hampir semua kajian melaporkan 
bahwa proseksi dan diseksi tidak dapat ditinggalkan karena memberi pengalaman nyata tiga dimensi yang tidak tergantikan, meskipun oleh program anatomi digital yang paling canggih saat ini. ${ }^{16,17}$

Pemanfaatan cadaver memberi manfaat yang besar dan bermakna, meliputi pengalaman emosional yang mendalam, menumbuhkan penghargaan terhadap jasad manusia yang sangat berpengaruh bagi pembentukan perilaku professional para mahasiswa. ${ }^{18-22}$ Alhassan \& Majeed ${ }^{23}$ menunjukkan adanya persepsi positif yang kuat terhadap diseksi cadaver dalam pembelajaran anatomi pada institusi yang menggunakan kurikulum Problem-basedlearning (PBL) di Ghana. Para mahasiswa umumnya sepakat bahwa diseksi cadaver memperdalam pemahaman anatomy $(87.9 \%)$, membekali pemahaman yang lebih baik untuk ujian ketrampilan klinis (66.7\%), memperkuat penghormatan terhadan tubuh manusia $(66.6 \%)$, membekali pemahaman yang lebih baik tentang akibat trauma (69.7\%), dan membuat pembelajaran lebih menarik. Meski 57.5\% diantara mereka sepakat bahwa diseksi adalah menimbulkan stress, namun tidak setuju bila diseksi dihapus dari kurikulum (100\%).
Survey global yang melibatkan pengajar anatomi dari 29 negara mengungkap bahwa 80\% mengindikasikan perlunya mahasiswa kedokteran dan kesehatan mengerjakan diseksi cadaver. Selain itu terekam bahwa diseksi merupaka instrumen untuk melatih mahasiswa membantu mengendalikan emosi, pengembangan ketrampilan klinis, sikap dan perilaku profesional selanjutnya yang lebih luas dari sekedar sarana belajar anatomi. ${ }^{24}$ Beberapa kajian bahkan menyatakan bahwa diseksi cadaver merupakan keharusan dalam pendidikan kedokteran baik tahap sarjana hingga tahap lanjut, terutama dalam pendidikan keahlian terkait pembedahan. ${ }^{25-27}$ Ada pula wacana bahwa dengan berkurangnya peran anatomi di tahap pendidikan kedokteran dasar maka menjadi sangat diperlukan di tahap klinik, bahkan perlu lebih ditekankan bahwa anatomi merupakan disiplin yang tak terpisahkan dalam kelompok klinik. ${ }^{27,28}$ Beberapa institusi yang maju memang menawarkan beragam paket pembelajaran dan pelatihan anatomi klinik canggih yang memanfaatkan cadaver dengan biaya yang tidak kecil.

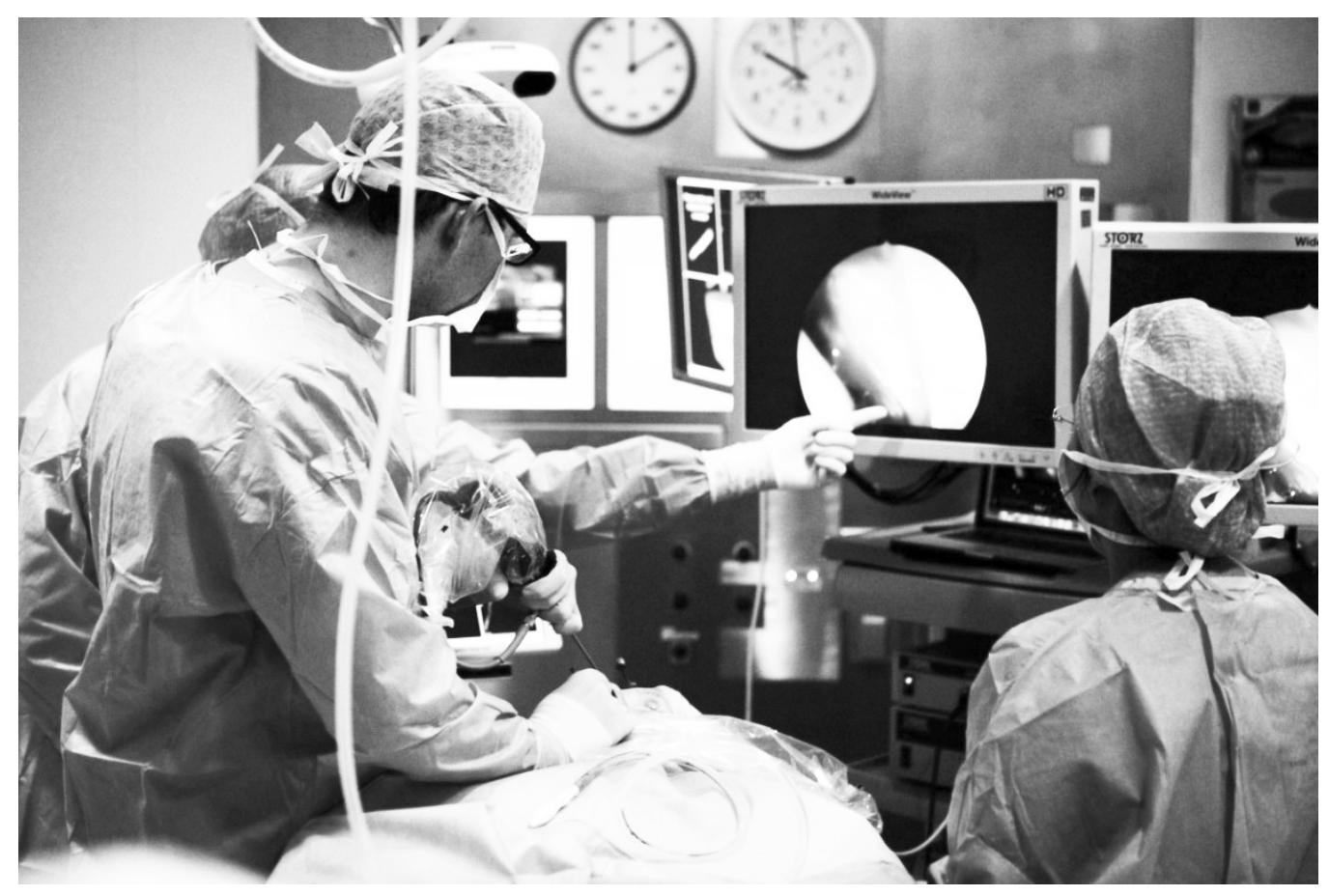

Gambar 1. Endoscopic Sinus Surgery by Cadaver Dissection, Dundee Institute for Healthcare Simulation, University of Dundee. ${ }^{29}$ 
Dari uraian diatas dapat dirangkum bahwa cadaver merupakan sumber ajar yang memberi berbagai manfaat, antara lain: 1) memperkuat penghormatan terhadap tubuh manusia; 2) melatih pengendalian emosi dan mengatasi stress; 3) pengembangan bioetika, identitas, sikap dan perilaku profesional; 4) memperdalam pemahaman anatomi dan patologi; dan 5) melandasi pemahaman untuk menunjang ketrampilan klinis terutama pada pendidikan keahlian lanjut (residensi) yang terkait pembedahan.

\section{Ketersediaan Cadaver}

Pada awalnya pasokan cadaver cukup bersumber dari para kriminal yang dieksekusi, karena keperluannya masih sangat terbatas. Dengan meningkatnya minat diseksi untuk berbagai kepentingan, sejak sekitar abad pertengahan sempat terjadi malpraktek seperti pembegalan, pencurian dan jual-beli mayat, bahkan pembunuhan, sehingga menimbulkan polemik yang berkepanjangan. Penguasa Inggris pada tahun 1752 menerbitkan Murder Act yang memperbolehkan pelaku kriminal yang dihukum gantung untuk dikirim ke kamar diseksi. Aturan ini menjawab setidaknya dua masalah yaitu: memenuhi keperluan diseksi dan menekan angka kriminal. Pada umumnya masyarakat memandang bahwa perlakuan diluar pemakaman yang lazim merupakan ancaman hukum yang perlu dihindari sehingga diseksi diharap dapat mengurangi atau mencegah tindak pidana. Pada pertengahan abad 18 terbit aturan yang memperbolehkan diseksi dari jasad takdikenal (unclaimed), narapidana, orang miskin dari rumahsakit jiwa dan 'charity'. Pemerintah Inggris pada tahun 1832 menerbitkan Warburton Anatomy Act yang membuka peluang bagi hibah jasad secara sukarela. Kondisi yang serupa juga terjadi di benua Amerika, antara lain ditandai dengan adanya Massachusetts Law pada tahun 1833. Polemic tentang sumber cadaver terus berlanjut karena dinilai terutama berasal dari kalangan yang terpinggirkan (marginal). ${ }^{2}$

Dengan berkembangnya bedah transplantasi dan makin meningkatnya keperluan bahan anatomi, maka pada tahun 1968 di Amerika muncul Uniform Anatomical Gift Act (UAGA), yang mengatur lebih rinci bagi mereka yang berminat memberikan hibah jasad. Selanjutnya berbagai upaya promosi donor organ maupun hibah jasad manusia cukup giat dilakukan di berbagai belahan dunia. Pada 1984 pemerintah Inggris menerbitkan Anatomy Act dengan tujuan menyederhanakan proses hibah jasad. Kriteria penerimaan donor cukup dengan pernyataan tertulis atau lisan yang disaksikan oleh dua orang atau lebih niatan untuk menghibahkan jasadnya setelah meninggal. Kemudian donor diberi penjelasan lengkap termasuk setiap langkah yang akan dilakukan sejak dari niat untuk donasi hingga perlakuan terakhir terhadap tubuhnya yang tersisa. ${ }^{30}$ Ternyata tanggapan masyarakat cukup positif, sehingga sebagian besar cadaver bersumber dari hibah jasad. Lembaga European Federation for Experimental Morphology (EFEM) pada 2005 mengeluarkan rekomendasi guna perbaikan praktek hibah jasad. Sangat ditekankan perlunya inform consent, diadakannya layanan upacara untuk memperingati dan mengungkapkan terima kasih terhadap pendonor dan keluarganya. Selain itu perlu ada kuliah khusus bioetika bagi seluruh mahasiswa yang mengambil manfaat dari cadaver untuk mengembangkan kepekaan yang memadai dan menjamin tindakan dan penghormatan sesuai yang diharapkan selama menjalami pendidikan dan riset. ${ }^{31,32}$

Pada tahun 2012, International Federation of Associations of Anatomists (IFAA) menerbitkan rekomendasi tentang perlunya memasyarakatkan hibah jasad dan upaya mengakhiri penggunaan cadaver yang mengandung kontroversi etis. Cadaver yang berasal dari eksekusi terpidana dan terutama jasad tak dikenal mengundang kritik karena alasan tanpa persetujuan mereka dan diskriminasi terhadap kelompok marginal, seperti kaum minoritas, penderita sakit jiwa dan golongan miskin. Pelaksanaan rekomendasi tersebut perlu dicermati, namun sejauh ini informasi mengenai hal ini masih sangat kurang. Suatu tinjauan menyeluruh (overview) tentang sumber cadaver di penjuru dunia dikerjakan oleh Habicht. ${ }^{33}$ Informasi diperoleh dari 71 negara (43\%) diantara 165 negara yang mempunyai pendidikan kedokteran. Dari 68 negara yang memanfaatkan cadaver, 22 negara (32\%) hanya bersumber dari hibah jasad. Sebagian besar negara lainnya masih mengutamakan jasad tak 
dikenal ( $\mathrm{n}=18 ; 26 \%)$, atau bahkan hanya dari jasad tak dikenal $(n=21 ; 31 \%)$. Beberapa negara sisanya $(\mathrm{n}=7 ; 11 \%)$ juga melakukan impor cadaver, bahkan di satu negara jasad terpidana mati diserahkan ke Departemen Anatomi. Indonesia termasuk negara yang masih sangat bergantung pada jasad tak dikenal.

\section{Kondisi di Indonesia, Khususnya UGM}

Pertumbuhan institusi pendidikan kedokteran di Indonesia cukup pesat dalam dua dasawarsa terakhir. Oleh karena itu kesenjangan antara ketersediaan dan keperluan (supply and demand) cadaver menjadi semakin lebar. Tambahan lagi dengan peningkatan administrasi kependudukan maka adanya jasad tak dikenal yang sejauh ini merupakan sumber utama cadaver juga makin menurun. Departemen Anatomi FK UGM yang lahir tahun 1946 semula menerima cadaver yang cukup, namun sejak tahun 2000 hampir tidak ada lagi cadaver yang diterima. Dapat diperkirakan bahwa institusi yang lahir lebih akhir menghadapi permasalahan yang mungkin lebih berat.

Semula setiap mahasiswa kedokteran di FK UGM berkesempatan menjalankan diseksi cadaver secara langsung. Namun dengan berbagai pertimbangan, maka sejak tahun 1990-an dalam pembelajaran anatomi tahap sarjana bersumber pada proseksi, mahasiswa hanya mempelajari bahan yang telah disiapkan oleh pakar anatomi. Pertimbangan yang mendasari antara lain terbatasnya masa studi, makin sedikitnya ketersediaan cadaver dan tenaga ahli anatomi. Diseksi langsung hanya diikuti oleh mahasiswa dengan minat khusus yang mendaftar (elektif) dan tahap pascasarjana atau residensi. Untuk mengatasi keterbatasan pasokan cadaver kemudian dikembangkan Bengkel Anatomi guna membuat beberapa replika dan manekin sejak tahun 2000-an.

Hibah jasad manusia di Indonesia sebenarnya sudah dijalankan. Pada tahun 2011 seorang dosen di UGM telah diterima hibah jasadnya oleh Fakultas Kedokteran UGM. Semasa hidup beliau telah menyatakan niat tersebut yang dicatat di depan notaris, dilengkapi persetujuan pasangan dan anak selaku ahli waris. Setelah momen yang sangat cukup bersejarah itu, FK UGM menerima beberapa pernyataan lisan yang menyatakan kesediaan untuk menghibahkan jasadnya bila meninggal. Namun perangkat hukum yang mengaturnya masih sangat

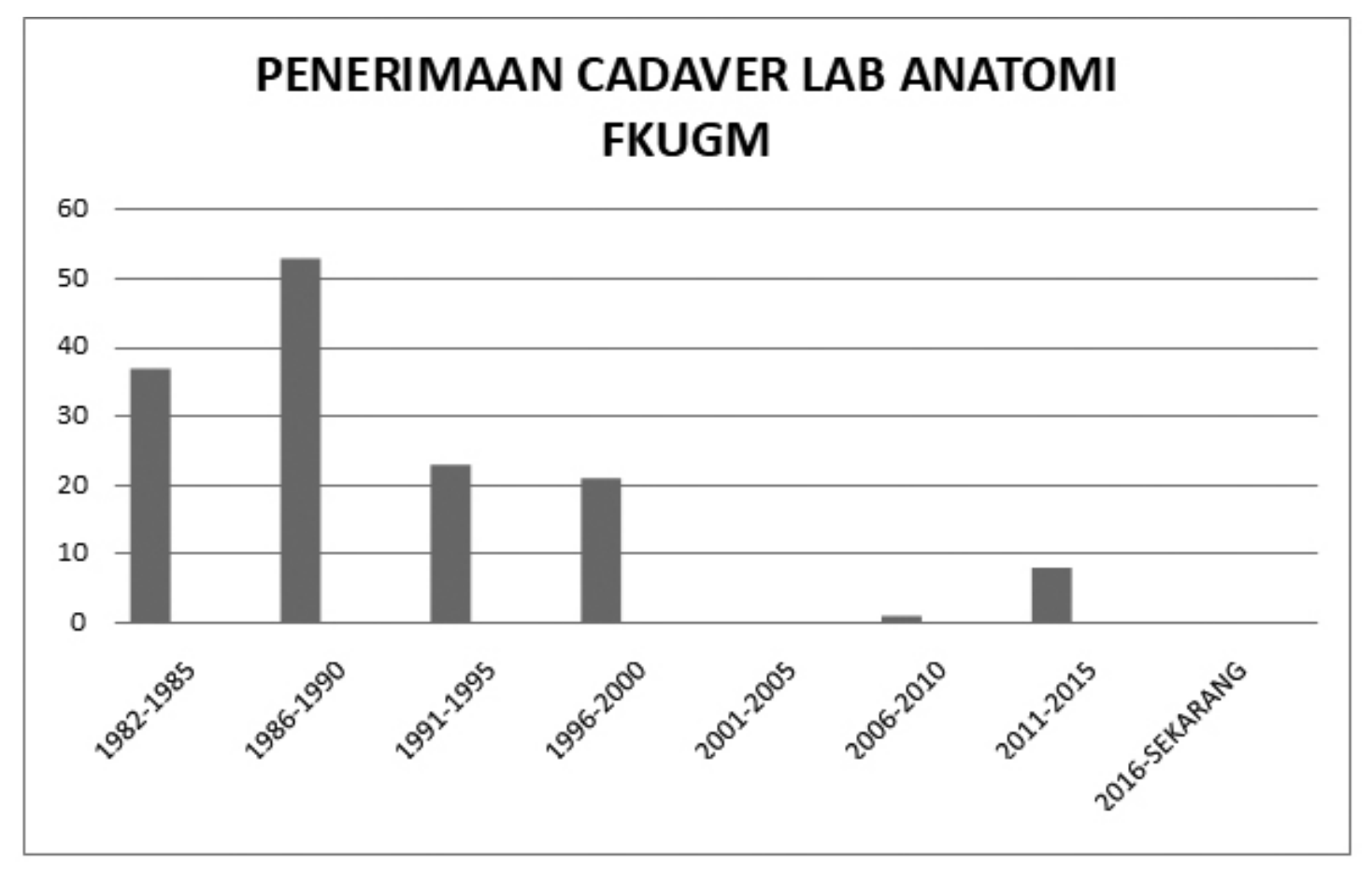

Gambar 2. Grafik penerimaan cadaver di Departemen Anatomi FK UGM sejak tahun 1982 
terbatas dan perlu pengembangan lebih lanjut. Aturan terkait yang ada hanya PP No.18 Tahun 1981 tentang Bedah Mayat Klinis dan Bedah Mayat Anatomis Serta Transplantasi Alat atau Jaringan Tubuh Manusia. Berkenaan dengan hal tersebut telah dilaksanakan pembahasan dalam Dialog Moral, Hukum dan Kemanusiaan tentang Donasi Tubuh dan Donor Organ oleh Pusat Bioetika dan Humaniora Kesehatan di FK UGM pada 2-3 Agustus 2017.34 Tindak lanjut masih diperlukan untuk menghasilkan aturan operasional yang rinci dan jelas, serta disosialisasikan dengan baik sehingga diharapkan hibah jasad akan makin meningkat.

\section{KESIMPULAN}

Pendidikan kedokteran terus berkembang pesat namun masih memerlukan cadaver yang memuat banyak manfaat, meski ketersediaannya yang merupakan jasad tak dikenal sangat menurun. Pemanfaatan cadaver perlu dipetakan berdasarkan jenjang pendidikan kedokteran, tingkat sarjana, pascasarjana, klinis atau spesialis. Inovasi kurikulum dapat sebagai terobosan untuk mengupayakan pemanfaatan cadaver secara efektif dan efisien. Sumber pembelajaran pengganti sebagai pelengkap perlu dikembangkan untuk menjamin peningkatan mutu pendidikan kedokteran. Perlu upaya yang melibatkan berbagai pemangku kepentingan, termasuk pakar hukum, untuk menerbitkan aturan yang rinci dan jelas agar dapat mendukung ketersediaan cadaver yang bersumber dari hibah jasad.

\section{SARAN}

Mengkaji berbagai permasalahan dalam uraian diatas perlu dilakukan berbagai upaya sebagai tindak lanjut. Cadaver yang diperoleh perlu dimanfaatkan untuk pembelajaran dan penelitian kedokteran secara selektif, efektif dan efisien. Pada tingkat dasar sumber pembelajaran dari proseksi, plastinasi atau museum anatomi. Diseksi cadaver diutamakan untuk pendidikan lanjut, khususnya keahlian klinik terkait pembedahan.

Selain itu, perlu dikembangkan rancangan kurikulum pendidikan kedokteran yang dapat memanfaatkan cadaver untuk berbagai tujuan dengan mempertimbangkan jenjang pendidikan. Pada tahap paling awal cadaver dirancang untuk penghormatan terhadap manusia, pembinaan etika dan perilaku professional. Pada jenjang selanjutnya cadaver dimanfaatkan untuk pemahaman dasar kedokteran dan kesehatan. Pada tahap keahlian lanjut, khususnya yang tekait pembedahan, justru sangat perlu diseksi cadaver dan anatomi klinik untuk pemahiran ketrampilan.

Lebih lanjut, perlu dikembangkan sumber belajar pelengkap selain cadaver dengan memanfaatkan teknologi pencitraan (imaging), teknologi informasi dan komunikasi, cetak 3D (3D printing) dan teknologi lain yang mendukung pembelajaran dan penelitian kedokteran dan kesehatan pada umumnya.

Sangat diperlukan pengembangan perangkat hukum yang rinci dan jelas tentang hibah jasad, dengan peran serta para ahli yang terkait dan berbagai pemangku kepentingan. Selanjutnya diadakan sosialisasi kepada masyarakat luas akan keperluan dan manfaat hibah jasad.

\section{DEKLARASI KEPENTINGAN}

Penulis menyatakan bahwa manuskrip dan penelitian ini tidak memiliki konflik kepentingan apapun.

\section{DAFTAR PUSTAKA}

1. Bergman EM. Discussing dissection in anatomy education. Perspect Med Educ. 2015;4:211-3.

2. Ghosh SK. Human cadaveric dissection: a historical account from ancient Greece to the modern era. Anat Cell Biol. 2015;48:153-69.

3. Farey JE, Bui DT, Townsend D, Sureshkumar P, Carr $S$ and Roberts C. Predictors of confidence in anatomy knowledge for work as a junior doctor: a national survey of Australian medical students. BMC Med Educ. 2018;18:174-81.

4. Kim DH, Shin DH, Hwang Yl. Effects of alternate dissection on anatomy learning. Anat Cell Biol. 2019;52:69-75.

5. Ellis H. Medico-legal litigation and its links with surgical anatomy. Surgery. 2002;20:i -ii.

6. Older J. Anatomy: a must for teaching the next generation. J R Coll Surg. 2004;2(2):79-90. 
7. von Staden H. The discovery of the body: human dissection and its cultural contexts in ancient Greece. Yale J Biol Med. 1992;65:223-41.

8. Bay NSY, Bay BH. Greek anatomist Herophilus: the father of anatomy. Anat Cell Biol. 2010;43:280-3.

9. Standring S. A brief history of topographical anatomy. J Anat. 2016; 229: 32--62.

10. Edriss H, Rosales BN, Nugen C, Conrad C, Nugent $\mathrm{K}$. Islamic medicine in the middle ages. Am J Med Sci. 2017;354(3):223-9.

11. Habbal O. The Science of Anatomy A historical timeline. Sultan Qaboos Univ Med J. 2017;17(1):e18-22.

12. Compier AH. Rhazes in the Renaissance of Andreas Vesalius. Med History. 2012;56:3-25.

13. Memon I. Anatomy education faces challenges in Pakistan. Anat Sci Educ. 2009;2(4):193-4.

14. EwonuBari EB, Watson JT, Amaza DS, Madueke NM, Donatus AA, Effiong OE. Problems and prospects of acquistion of human cadaver for medical education in Nigeria. J Pakist Med Assoc. 2012;62:1134-6.

15. Patel SB, Mauro D, Fenn J, Sharkey DR, Jones C. Is dissection the only way to learn anatomy? Thoughts from students at a non-dissecting based medical school. Perspect Med Educ. 2015;4:259-60.

16. Papa V, Vaccarezza M. Teaching Anatomy in the XXI Century: New Aspects and Pitfalls. Sci World J. 2013 ; Article ID 310348, 5pages. http://dx.doi. org/10.1155/2013/310348.

17. Flack NAMS, Nicholson HD. What do medical students learn from dissection? Anat Sci Educ. 2018;11(4):325-35 doi: 10.1002/ase.1758. Epub 2017 Dec 4.

18. Winkelmann A, Güldner FH. Cadavers as teachers: the dissecting room experience in Thailand. BMJ. 2005;329:18-25.

19. Khan HM, Mirza TM. Physical and psychological effects of cadaveric dissection on undergraduate medical students. J Pakist Med Assoc. 2013;63: 831.

20. Sándor I, Birkas E, Gyorffy Z. The effect of dissection room experiences and related coping strategies among Hungarian medical students. BMC Med Educ. 2015;15:73 DOI 10.1186/s12909. 015-0355-9.

21. Chiou RJ, Tsai PF, Han DY. Effects of a "silent mentor" initiation ceremony and dissection on medical students' humanity and learning. BMC Res Notes. 2017;10:483 DOI 10.1186/s13104-0172809-0.
22. Chang HJ, Kim HJ, Rhyu IJ, lee YM, Uhm CS. Emotional experiences of medical students during cadaver dissection and the role of memorial ceremonies: a qualitative study. BMC Med Educ. 2018;18:255 https://doi.org/10.1186/s12909-0181358-0.

23. Alhassan A, Majeed S. Perception of Ghanaian Medical Students of Cadaveric Dissection in a Problem-Based Learning Curriculum. Anat Res Internat. 2018; 2018, Article ID 3868204, 7 pages https://doi.org/10.1155/2018/3868204.

24. Arraez-Aybar LA, Bueno-Lopez JL, Moxham BJ. Anatomists' views on human body dissection and donation: an international survey. Annals Anat. 2014;196:376-86.

25. Krähenbühl SM, Cvancara P, Stieglitz T, Bonvin R, Michetti M, Flahaut M, et al. Return of the cadaver. Medicine. 2017;96:29.

26. Memon I. Cadaver Dissection Is Obsolete in Medical Training! A Misinterpreted Notion. Med Princ Pract. 2018;27:201-10.

27. Ghazanfar H, Rashid S, Hussain A, Ghazanfar M, Ghazanfar A, Javaid A. Cadaveric Dissection a Thing of the Past? The Insight of Consultants, Fellows, and Residents. Cureus. 2018;10(4):e2418. DOI 10.7759/cureus.2418.

28. Fasel JHD, Morrel P, Gaillaud P. A survival strategy for anatomy. Lancet. 2005;365:754.

29. University of Dundee. Endoscopic Sinus Surgery by Cadaver Dissestion for Healthcare Simulation. Dundee: University of Dundee; 2018. Available on: https://dihs.dundee.ac.uk/courses/ent-thiel/ endoscopic-sinus-surgery-cadaver-dissection-fess1.

30. Greene JR. Effects of detailed information about dissection on intentions to bequeath bodies for use in teaching and research. J Anat. 2003;202:475-7.

31. Nurunnabi ASM, Ara S, Khalil M, Khalil M. Ethics in dissection of cadaver in teaching and learning of anatomy. Bangladesh J Bioethics. 2011;2(3):10-5.

32. Ghosh SK. Paying respect to human cadavers: we owe this to the first teacher in anatomy. Annals Anat. 2017;211:129-34.

33. Habicht JL, Kiessling C, Winkelmann A. Bodies for Anatomy Education in Medical Schools: An Overview of the Sources of Cadavers Worldwide. Acad Med. 2018;93:1293-300.

34. Fakultas Kedokteran UGM, Dialog Moral, Hukum dan Kemanusiaan tentang Donasi Tubuh dan Donor Organ, Yogyakarta 2-3 Agustus 2017. 